\title{
New Data on Host Range and Geographical Distribution of Dothistroma Needle Blight in Ukraine ${ }^{+}$
}

\author{
Kateryna Davydenko ${ }^{1,2, *}$, Denis Baturkyn ${ }^{3}$, Ihor Hnoievyi ${ }^{4}$ and Olena Shcherbak ${ }^{4}$ \\ 1 Department of Forest Protection, G. M. Vysotskiy Ukrainian Research Institute of Forestry and Forest \\ Melioration, 61024 Kharkiv, Ukraine \\ 2 Department of Forest Mycology and Plant Pathology, Swedish University of Agricultural Sciences, \\ 75007 Uppsala, Sweden \\ 3 Forest Protection Service "Kharkivlisozahyst", 62458 Kharkiv region, Ukraine; baturkin.denis@ukr.net \\ 4 Kharkiv State Zooveterinary Academy, Kharkiv 62341, Ukraine; igor1810-1965-5555@rambler.ru (I.H.); \\ elenasherbak@ukr.net (O.S.) \\ * Correspondence: kateryna.davydenko74@gmail.com or Kateryna.davydenko@slu.se; Tel.: +38-050-859-66-87 \\ + Presented at the 1st International Electronic Conference on Forests - Forests for a Better Future: \\ Sustainability, Innovation, Interdisciplinarity, 24-27 June 2020; Available online: \\ https://iecf2020.sciforum.net.
}

Citation: Davydenko, K.; Baturkyn, D.; Hnoievyi, I.; Shcherbak, O. New Data on Host Range and Geographical Distribution of Dothistroma Needle Blight in Ukraine. Environ. Sci. Proc. 2021, 3, 89. https://doi.org/10.3390/ IECF2020-08086

Academic Editors: Angela Lo Monaco, Cate Macinnis-Ng and Om P. Rajora

Published: 13 November 2020

Publisher's Note: MDPI stays neutral with regard to jurisdictional claims in published maps and institutional affiliations.

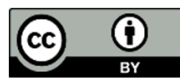

Copyright: $₫ 2020$ by the authors. Licensee MDPI, Basel, Switzerland. This article is an open access article distributed under the terms and conditions of the Creative Commons Attribution (CC BY) license (http://creativecommons.org/licenses /by/4.0/).

\begin{abstract}
Serious pine needle disease, Dothistroma needle blight (DNB), caused by Dothistroma septosporum and D. pini was detected in Ukraine in the period 2004-2005. The aim of this study was to identify the Dothistroma species present on new hosts in Ukraine using different molecular techniques to increase our understanding of the local distribution of these pathogens. The occurrence and distribution of DNB were studied between the years 2014 and 2018, and 480 needle samples were collected from 16 different regions in 96 localities - the presence of DNB was confirmed in 62 of them. The host range of DNB consisted of eight pine species, including three subspecies and two spruce species, among them Pinus nigra subsp. pallasiana and P. sylvestris were the most frequent hosts. Results showed that both D. septosporum and D. pini were present on P. nigra subsp. pallasiana on the same trees and even in the same needles. Moreover, D. septosporum was found first in Ukraine on Pinus ponderosa Douglas, Pinus banksiana Lamb and Pinus contorta Douglas in the arboretum as well as Picea pungens Engelm and Picea abies (L.) H. Karst. The suitability for the disease in the different forest types and the intensity of the disease are discussed.
\end{abstract}

Keywords: Dothistroma needle blight; pine species; disease intensity

\section{Introduction}

Dothistroma needle blight (DNB) has been reported as one of the most serious diseases of conifers with a worldwide distribution and over 100 reported pine host species [1]. DNB is caused by the two morphologically similar ascomycetous fungal species Dothistroma septosporum (Dorog.) M. Morelet and Dothistroma pini Hulbary [2] and only molecular markers are capable of distinguishing these two species [1,2]. D. septosporum has a worldwide distribution, while $D$. pini has been found in the US and in more than 10 European countries such as France, Hungary, Ukraine, Switzerland [1-5].

D. septosporum was first recorded in Ukraine in 1914 in pine plantation and this sample was collected by L. Kaznovsky on Pinus sylvestris L. needles nearby Smela (Kiev province, 25 March 1914; LE 116244, duplicate-CBS 11381) [2]. This species was identified as Dothistroma septosporum. Second findings in Ukraine in Mykolaiv and Kherson regions were collected in 2004; DNB was found on Pinus nigra subsp. Pallasiana, (Crimean pine) in Ukraine [2] and this species was identified as D. pini [3]. Ukrainian isolates from $P$. nigra subsp. pallasiana were identified as $D$. pini based on both the internal transcribed spacer (ITS) and the -tubulin sequences [3], presenting the first verified report of this 
fungus outside North-Central USA. Hence, D. pini is now known to occur on two continents in 76 countries, and the host range includes 20 newly reported hosts of Dothistroma species [1]. Moreover, two new exotic pine hosts for D. septosporum, Pinus nigra var. australica and P. nigra var. mollet were recorded in western Ukraine [6].

The aim of this study was to identify the Dothistroma species present on new hosts in Ukraine using different molecular techniques to increase our understanding of the local distribution and disease intensity of these pathogens.

\section{Experimental Section}

For DNB detection, only symptomatic needles were collected in Ukraine in the period 2014-2018 from 10- to 40-year-old Scots pine (Pinus sylvestris) and from other exotic pine species of different ages in 10 different localities (Table 1). The disease intensity was assessed visually as the rate of the tree crown affected by DNB [7] as follows: up to $20 \%$ of crown damage is the low disease severity, $20-40 \%$ the middle one, $40-60 \%$ high and $>60 \%$ very high disease severity [7].

The 1-, 2- and 3-year-old infected needles were collected from 3 randomly selected trees in every locality (in total, 40-60 needles depending on disease intensity). Samples were placed in paper bags and kept at $-20{ }^{\circ} \mathrm{C}$ until processed in laboratory in the same year. Needles were examined with a Nikon C-PS stereo microscope in the laboratory and classified as symptomatic or asymptomatic. Isolations were made from mature conidiomata from symptomatic needles using the rolling method and $2 \%$ malt extract agar (MEA) to release conidia [3].

In addition to morphological analysis of fungal sporification structures, different DNA-based techniques were used for species identity. The DNA was extracted from symptomatic and asymptomatic needles from each location using the OMEGA E.Z.N.A. Bio-Tek Fungal DNA Mini Kit D3390-02 (Omega Bio-tek, Doraville, GA, USA), following the manufacturer's instructions. Conventional PCR with specific primers was used to identify the fungus directly in DNA extracted from needles (DStub2-Forward (CGAACATGGACTGAGCAAAAC) and DStub2-Reverse (GCACGGCTCTTTCAAATGAC) for D. septosporum and DPtef-Forward (ATTTTTCGCTGCTCGTCACT) and DPtef-Reverse (CAATGTGAGATGTTCGTCGTG) for identification of D. pini [3]. The identity of Dothistroma species from culture was confirmed by sequencing the internal transcribed spacer (ITS) region using the primers ITS5 and ITS 4 [8] and $\beta$-tubuline gene region 2 was amplified using the primers using the primers $\mathrm{Bt} 2 \mathrm{a}$ and $\mathrm{Bt} 2 \mathrm{~b}[3]$.

\section{Results}

The occurrence and distribution of DNB were studied in the years 2014-2018, and 480 needle samples were collected from 16 different regions in 96 localities-the presence of DNB was confirmed in 62 of them.

Visual symptoms of DNB observed on needles varied significantly. A clear DNB symptoms were present on individual trees, but most of the signs were controversial [3], and typical DNB red bands were not generally occurring on infected needles of Pinus contorta and Picea pungens. Infected needle generally starts to appear on basal part of trees infecting 2-, 3-year-old needles of lower branches. DNB in Ukraine is commonly found on ornamental pines in Arboretum, and Botanical gardens, although no middle/high damage has been observed. Moreover, damage rate was quite low, and pathogen was presented only on lower branches.

The host range of DNB consisted of eight pine species, including three subspecies and two spruce species, among them Pinus nigra subsp. pallasiana and P. sylvestris L. were the most frequent hosts. Diseased pine trees with DNB symptoms were found in various habitats, including planted pine forests and arboretums throughout the country that partially presented in Table 1. Based on a molecular analysis, both $D$. septosporum and $D$. 
pini were present on P. nigra subsp. pallasiana on the same trees and even in the same needles.

Table 1. New data on host and locality of Dothistroma needle blight (DNB) in Ukraine (only part of data is shown).

\begin{tabular}{|c|c|c|c|c|}
\hline Host & Locality & Coordinates & $\begin{array}{c}\text { D. septosporum } \\
\text { ITS/ } \\
\beta \text {-tubulin } \\
\end{array}$ & $\begin{array}{c}\text { D. pini } \\
\text { ITS/ } \\
\beta \text {-tubulin }\end{array}$ \\
\hline \multirow{3}{*}{ Pinus sylvestris } & $\begin{array}{l}49.622576 \\
36.390355\end{array}$ & Kharkiv, Zmyiv district & $+/-$ (same trees and needles) & $-/+$ (same trees and needles) \\
\hline & $\begin{array}{c}49.814551 \\
30.055763\end{array}$ & Bila Tserkva, Alexandria & $+/+$ & $-1-$ \\
\hline & $\begin{array}{c}50.047282 \\
31.396392\end{array}$ & Pereyaslavl & $+/+$ & $-1-$ \\
\hline $\begin{array}{l}\text { P. nigra subsp. } \\
\text { palassiana }\end{array}$ & $\begin{array}{c}50.382611 \\
30.500463\end{array}$ & Kyiv, Botanical Garden Holosiivskyi & $+/-$ (same trees and needles) & $+/+$ (same trees and needles) \\
\hline P. ponderosa & $\begin{array}{c}50.097505 \\
36.277293\end{array}$ & Kharkiv, URIFFM arboretum & $+/+$ & $-1-$ \\
\hline P. banksiana & $\begin{array}{c}50.027229 \\
36.229664\end{array}$ & Kharkiv, KhNU arboretum & $+/+$ & $-1-$ \\
\hline \multirow{2}{*}{ P. contorta } & $\begin{array}{c}50.027229 \\
36.229664 \\
\end{array}$ & Kharkiv, KhNU arboretum & $+/+$ & $-1-$ \\
\hline & $\begin{array}{c}48.765469 \\
30.236940\end{array}$ & Uman, arboretum & $+/-$ & $-1-$ \\
\hline Picea pungens & $\begin{array}{c}50.027229 \\
36.229664\end{array}$ & Kharkiv, KhNU arboretum & $+/+$ & $-1-$ \\
\hline Picea abies & $\begin{array}{c}50.097505 \\
36.277293 \\
\end{array}$ & Kharkiv, URIFFM arboretum & $+/+$ & $-1-$ \\
\hline Abies concolor & $\begin{array}{c}50.027229 \\
36.229664\end{array}$ & Kharkiv, KhNU arboretum & $-1-$ & $-1-$ \\
\hline
\end{tabular}

Moreover, the Dothistroma septosporum was found and molecularly confirmed first in Ukraine on five non-native conifers Pinus ponderosa, Pinus banksiana and Pinus contorta in the arboretum as well as Picea pungens and P. abies in Botanical gardens and arboreta (Table 1).

\section{Discussion}

Having analyzed the distribution of DNB in pine forests, disease severity of infection in Scots pine forest stands and plantations was not very high. The highest disease severity, up to $80 \%$, has been observed in the southern regions on $P$. nigra subsp. pallasiana. On Pinus banksiana and Pinus ponderosa, a DNB was confirmed by only morphological and molecular methods, and no typical DNB symptoms and pathogen outbreak have been observed since the survey. The analysis of geographical distribution and host range data indicates that DNB is spreading across Ukraine in various habitats, wherever both pine forest and other exotic pines are present. DNB was found in many parts of the country although the disease intensity is low, probably due to the unfavorable climate conditions for DNB development.

Obtained results in this study showed the ability of Dothistroma species to infect the conifers and to cause the damages and different needle losses, but there was no significant influence of diseases intensity with Dothistroma species on the tree decline and dieback. However, further large-scale field and pathogenicity studies are required to support this conclusion.

DNB is a serious problem, affecting most of the European countries, and one of the main goals in the possible management strategies is the determination of all the contributing factors of conifer decline in Europe. However, next to infections of DNB as a main cause of the needle dieback, some other pathogens may possibly play a role in this phenomenon, including infections with root rot, rust and Armillaria species [9]. Therefore, further study of possible interactions of DNB and other pathogens, as well as patho- 
genicity tests, is required to understand their common impact on conifers and other possible interactions.

\section{Conclusions}

The data obtained demonstrated gradual increasing of the geographical range of DNB in Ukraine. In addition to the eight existing pine species, D. septosporum was found first in Ukraine on Pinus ponderosa Douglas, Pinus banksiana Lamb and Pinus contorta Douglas in the arboretum, as well as Picea pungens Engelm and Picea abies (L.) H. Karst. The suitability for the disease in the different forest types and the intensity of the disease are different throughout the country, although generally the disease intensity is low, probably due to the unfavorable climate conditions for DNB development.

Author Contributions: Conceptualization, K.D. and O.S.; methodology, K.D., D.B. and I.H.; software, D.B., I.H.; formal analysis, K.D., D.B. and O.S.; investigation, K.D., D.B. and O.S.; resources, D.B. and I.H.; writing-original draft preparation, K.D.; writing - review and editing, K.D., D.B., I.H. and O.S.; project administration, I.H. and O.S. All authors have read and agreed to the published version of the manuscript.

Data Availability Statement: The data presented in this study are available on request from the corresponding author.

Acknowledgments: This work was supported by COST Action FP1102 DIAROD (Determining Invasiveness and Risk of Dothistroma. The research was supported by the Ministry of Education and Science of Ukraine within joint Ukrainian-Lithuanian project No. M/93-2018 (biological control of forest invasive pathogens to preserve biodiversity in European noble forest and woodland ecosystems).

Conflicts of Interest: The authors declare no conflict of interest.

\section{References}

1. Drenkhan, R.; Tomešová-Haataja, V.; Fraser, S.; Vahalik, P.; Mullett, M.; Martín-García, J.; Bradshaw, R.E.; Bulman, L.; Wingfield, M.J.; Kirisits, T.; et al. Global geographic distribution and host range of Dothistroma species: A comprehensive review. For. Pathol. 2016, 46, 408-442.

2. Barnes, I.; Crous, P.W.; Wingfield, B.D.; Wingfield, M.J. Multigene phylogenies reveal that red band needle blight of Pinus is caused by two distinct species of Dothistroma, D. septosporum and D. pini. Stud. Mycol. 2004, 50, 551-565.

3. Barnes, I.; Kirisits, T.; Akulov, A.; Chhetri, D.B.; Winhfield, B.D.; Bulgakov, T.S.; Wingfield, M.J. New host and country records of the Dothistroma needle blight pathogens from Europe and Asia. For. Pathol. 2008, 38, 178-195.

4. Barnes, I.; Kirisits, T.; Winhfield, B.D.; Wingfield, M.J. Needle blight of pine caused by two species of Dothistroma in Hungary. For. Pathol. 2011, 41, 361-369.

5. Ioos, R.; Fabre, B.; Saurat, C.; Fourrier, C.; Frey, P.; Marcais, B. Development, comparison, and validation of Real-Time and conventional PCR tools for the detection of the fungal pathogens causing brown spot and red band needle blights of pine. Phytopathology 2010, 100, 105-114.

6. Matsiakh, I.; Doğmuş-Lehtijärvi, H.T.; Kramarets, V.; Aday Kaya, A.G.; Oskay, F.; Drenkhan, R.; Woodward, S. Dothistroma spp. in western Ukraine and Georgia. For. Pathol. 2018, 48, e12409.

7. Markovskaja, S.; Raitelaitytė, K; Kačergius, A.; Kolmakov, P.; Vasilevich, V. Occurrence of Dothistroma needle blight in Lithuania and Belarus: The risk posed to native Scots Pine forests. For. Pathol. 2020, 50, e12626.

8. White, T.J.; Bruns, T.; Lee, S.; Taylor, J. Amplification and direct sequencing of fungal ribosomal RNA genes for phylogenetics. In PCR Protocols: A Sequencing Guide to Methods and Applications; Innis, M.A., Gelfand, D.H., Sninsky, J.J., White, T.J., Eds.; Academic Press: San Diego, CA, USA, 1990; pp. 315-322.

9. Wyka, S.A.; Munck, I.A.; Brazee, N.J.; Broders, K.D. Response of eastern white pine and associated foliar, blister rust, canker and root rot pathogens to climate change. For. Ecol. Manag. 2018, 423, 18-26. 